\title{
Stefnumiðað árangursmat sem liður í að framkvæma stefnu
}

\author{
Snjólfur Ólafsson ${ }^{1}$
}

\begin{abstract}
Ágrip
Grein pessi er tilraun til að greina og lýsa pví hvaða pátt stefnumiðað árangursmat (Balanced Scorecard) getur leikið í vinnu fyrirtækja og stofnana við að framkvæma stefnu sína. Í upphafi er fjallað um merkingu orðsins stefna (strategy) pví að skýr merking pess er forsenda fyrir markvissri umfjöllun um framkvæmd stefnu. Einnig má ætla að skýr stefna sé forsenda fyrir markvissri framkvæmd hennar. Stefna er orð sem hefur verið notað um mörg hugtök en í pessari grein er pað notað í merkingunni „lýsing á peim árangri sem stefnt er að og hvernig honum skuli náð“.

Stefnumiðað árangursmat er aðferðafræði sem má útfæra og nota á margan hátt. Kaplan og Norton kynntu aðferðafræðina fyrst árið 1992 en peir hafa próað hana mikið síðan pá. Í pessari grein er fjallað um kjarna aðferðafræðinnar og tvö verkfæri hennar, stefnukort og skorkort. Síðan er gerð tilraun til að draga fram pað hlutverk sem stefnumiðað árangursmat getur leikið í framkvæmd stefnu. Við pá greiningu er farið yfir helstu atriði sem parf til að framkvæma stefnu.
\end{abstract}

\section{Abstract}

The paper describes the role of the Balanced Scorecard in strategy execution. The meaning of the concept strategy is discussed as well as strategy execution. Strategy is defined as the description of the results which are strived for (objectives) and how they are to be obtained.

Kaplan and Norton presented the Balanced Scorecard methodology in 1992 but have developed it much since then. The paper explains the core of the method and it two tools, strategy map and scorecard. Then the content of strategy execution is discussed and finally, the role of the Balanced Scorecard in strategy execution is analysed.

JEL flokkun: M10

Lykil hugtök: Framvæmd stefnu; stefna; stefnumiðað árangursmat.

${ }^{1}$ Höfundur er prófessor í Viðskipta- og hagfræðideild Háskóla Íslands. 


\section{Inngangur}

Sum fyrirtæki hafa mjög skýra og vel útfærða stefnu (strategy), önnur virðast ekki hafa neina stefnu en flest eru stödd einhvers staðar par á milli. Рað sama gildir um aðrar skipulagsheildir, svo sem stofnanir og félagasamtök. Meðal stjórnenda og fræðimanna er sú skoðun útbreidd að æskilegt sé að skipulagsheildir hafi skýra stefnu en skiptar skoðanir eru um hvað í pví felst eða skuli felast. Í kafla 2 verður rætt um hugtakið stefna og pví gefin skýr merking.

Framkvæmd stefnu felst í mörgu og enginn vegur er að gera grein fyrir pví pannig að allir séu sáttir. Jafnvel mætti segja að í framkvæmd stefnu felist öll starfsemi skipulagsheildarinnar en slík skilgreining væri gagnslaus. Eðlilegra er að skilgreina hugtakið mun prengra, t.d. „vinna sem er unnin sérstaklega í pví augnamiði að koma stefnu skipulagsheildarinnar í framkvæmd“.

Stefnumiðað árangursmat (samhæft árangursmat, Balanced Scorecard) er aðferðafræði sem er sett sérstaklega fram til að lýsa stefnu og auðvelda pað að hrinda henni í framkvæmd. Mikill fjöldi fyrirtækja og stofnana hefur innleitt pessa aðferðafræði á einn eða annan hátt. Í greininni er staldrað við og reynt að greina pátt stefnumiðaðs árangursmats í framkvæmd stefnu.

Í kafla 3 er gefið yfirlit yfir pað helsta sem getur falist í framkvæmd stefnu en í kafla 7 er fjallað sérstaklega um pann pátt sem stefnumiðað árangursmat getur leikið í peirri framkvæmd.

Í kafla 4 er gerð grein fyrir stefnumiðuðu árangursmati og próun aðferðafræðinnar. Stefnumiðað árangursmat býður upp á tvö verkfæri, stefnukort (strategy map) og skorkort (scorecard) sem bæði má útfæra og nota á marga vegu. Pessi verkfæri verða skoðuð sérstaklega í köflum 5 og 6 .

Við greininguna er stuðst við bækur og tímarit, samtöl og erindi, fjölmörg verkefni meistaranema við Háskóla Íslands og reynslu höfundar af aðferðafræðinni, m.a. sem ráðgjafa.

\section{Stefna}

Hafsjór af bókum og greinum fjalla um stefnumótun og fjölmargir ráđgjafar vinna við að aðstoða fyrirtæki við að móta stefnu en prátt fyrir pað eru menn langt frá pví sammála um hvað felist í orðinu og hugtakinu stefna (strategy).

Par sem meginviðfangsefni pessarar greinar er framkvæmd stefnu er æskilegt að stuðst sé við skýra merkingu á hugtakinu stefna. Í pessari grein verður stuðst við eftirfarandi skilgreiningu á stefnu fyrir skipulagsheild eða hluta skipulagsheildar:

Stefna er lýsing á

peim árangri sem stefnt er að

og hvernig honum skuli náð.

Að mati höfundar falla flestar skilgreiningar á stefnu, í nýlegum bókum um efnið, vel að pessari skilgreiningu en með hvaða hætti pað er verður ekki krufið hér. 
Í sumum tilvikum er megináhersla stefnunnar lögð á árangurinn, í öðrum á leiðirnar (hvernig árangrinum skuli náð) og stundum er jöfn áhersla lögð á hvort tveggja. Í pessari skilgreiningu felst sama hugsun og kemur fram pegar talað er um „markmið og leiðir“, en árangurinn er pá markmiðið en lýsingin á pví hvernig árangrinum skuli náð er jafnframt lýsing á leiðinni. (Máltilfinning margra segir að íslenska orðið stefna lýsi meira árangrinum en enska orðið strategy lýsi meira hvernig honum skuli náð en í pessari skilgreiningu felst að bæði orðin nái yfir báða pættina.)

Árangri er stundum lýst sem framtíðarsýn eða markmiðum. Stundum er hlutverk fyrirtækisins dregið fram sem rökstuðningur en hér er ekki litið á hlutverkið sem hluta af stefnunni heldur frekar grundvöll stefnunnar eða eina af forsendum hennar.

Nota má margar aðferðir til að lýsa pví hvernig ætlunin sé að ná peim árangri sem fyrirtækið hefur sett sér að ná. Ein aðferð er að setja fram mörg undirmarkmið. Listi yfir aðgerðir getur verið hluti af lýsingunni. Ýmislegt annað getur líka átt við hér, svo sem að lýsa lykilárangurspáttum, áhersluatriðum, gildum eða skipulagsatriðum.

Venjulega er hluti stefnu fyrirtækis til á prenti (og á vefsíðum) en hluti aðeins í hugum manna. Oft er margt óljóst varðandi stefnuna, sérstaklega pá pætti sem ekki hafa verið settir fram á blaði.

Við skoðun á fjölmörgum vefsíðum íslenskra fyrirtækja á árinu 2003 kom í ljós að lýsingar par á stefnu viðkomandi fyrirtækis falla almennt vel að peirri skilgreiningu sem notuð er hér. Sem dæmi um lýsingu á stefnu par sem báðir pættirnir koma skýrt fram, en er fléttað saman í textanum, er stefna Össurar, en eftirfarandi texti er tekinn af vefsíðu Össurar 23. sept. '03:

Hlutverk Össurar er „að hjálpa fólki að njóta sín til fulls“. Мeð öðrum orðum reynir Össur að ryðja úr vegi líkamlegum hindrunum af völdum aflimunar með pví að framleiða bestu gervilimi sem völ er á og líkja eins og kostur er eftir peim útlim sem tapaðist. Sú pekking sem skapast hefur innan fyrirtækisins er grunnurinn að auknum vexti og nýsköpun í rannsóknar- og próunarstarfi fyrirtækisins. Össur kappkostar að vörur og pjónusta fyrirtækisins fari fram úr væntingum viðskiptavina og að halda áfram að vera leiðandi á markaði stoðtækja. Með pví að styrkja öflugt rannsóknar- og próunarstarf fyrirtækisins mun Össur halda áfram að framleiða framúrskarandi vörur sem miða að pví markmiði að auka lífsgæði aflimaðara einstaklinga. Fyrirtækið væntir að innri vöxtur verði tvisvar til prisvar sinnum meiri en almennt á stoðtækjamarkaði.

Stefna pjónar í grundvallaratriðum tveimur hagsmunahópum og pá á ólíkan hátt. Annar hópurinn er svokallaður ytri hópur, p.e. hluthafar og aðrir hagsmunaaðilar, t.d. viðskiptavinir og stjórnvöld. Hinn hópurinn er svokallaður innri hópur, stjórnendur og aðrir starfsmenn.

Hlutverk stefnu gagnvart ytri hópnum er einkum að auka tiltrú á skipulagsheildinni og upplýsa um starfsemi hennar. Framkvæmd stefnu snýr lítið að pessum hópi og er pví lögð lítil áhersla á hann í greininni. 
Grant (2002, bls. 28) dregur fram mismunandi hlutverk stefnu og er pá með innri hópinn í huga en hann segir að stefna geti pjónað prenns konar tilgangi:

- Stefna sem stuðningur við ákvarðanir. Grant bendir á að ákvarðanir geta ekki allar byggst á fullkomnum upplýsingum og rökréttri úrvinnslu úr peim. Stefnan getur pá stuðlað að pví að ákvarðanirnar séu innbyrðis samræmdar.

- Miðlun upplýsinga. Með pví að miðla upplýsingum um stefnuna til starfsmanna er verið að miðla upplýsingum um áherslur stjórnenda.

- Hvetjandi markmið. Í stefnunni koma fram markmið, stundum sett fram sem framtíðarsýn, sem hvetja menn til dáða.

Pegar talað er um stefnu skipulagsheildar er átt við stefnu varðandi alla starfsemina og mætti tala um æðstu stefnu. Hjá fyrirtækjum er pessi æðsta stefna gjarnan kölluð viðskiptastefna (business strategy).

Flest stór fyrirtæki og stofnanir hafa sett sér stefnu varðandi ýmsa pætti starfseminnar. Nú er t.d. algengt að birt sé starfsmannastefna á vefsíðum og margir hafa gæðastefnu, pjónustustefnu eða markaðsstefnu. Einnig má skilgreina stefnu fyrir hluta starfseminnar, t.d. stefnu fyrir hvert svið fyrirtækis. Pegar starfsemin er greind í nokkur lög (með skipuriti) geta svo verið enn fleiri stefnur, undirstefnur, t.d. fyrir deildir. Reyndar er ekki algengt að undirstefnur sem pessar séu settar fram með beinum hætti en nokkuð algengt er að sett séu fram markmið eða gerðar áætlanir fyrir svona einingar sem má líta á sem (ófullkomna) stefnu. Æðsta stefnan er í fæstum tilvikum mjög leiðbeinandi fyrir einstaka starfsmenn og pví parf oft undirstefnur til að koma stefnunni vel til skila til starfsmanna.

\section{Framkvæmd stefnu}

Í sumum skipulagsheildum reyna stjórnendur markvisst að framkvæma pá stefnu sem liggur fyrir. Ein af forsendum fyrir pví að unnt sé að framkvæma stefnu á markvissan hátt er að hún sé skýr en pað er engan veginn nægjanlegt skilyrði. Pvert á móti eru margar vísbendingar um að algengt sé að framkvæmd stefnu sé ómarkviss (sjá t.d. Beer \& Eisenstal 2000). Í pessum kafla er pað skoðað hvað átt er við með framkvæmd stefnu (strategy execution, strategy implementation).

Víðasta mögulega skilgreiningin á framkvæmd stefnu er að öll starfsemi í viðkomandi fyrirtæki eða stofnun sé liður í framkvæmd stefnunnar. Sú skilgreining er hins vegar gagnslaus og verður pví ekki notuð hér. Auk pess er hún í flestum eða öllum tilvikum röng pví að margt í starfsemi fyrirtækja og stofnana er á engan hátt í samræmi við stefnuna. Sem dæmi um slíkt er annars vegar að eigin hagur starfsmanna ræður oft miklu (gjaldprot Enron er skýrt dæmi um pað) og hins vegar að oft vita starfsmenn ekki hvernig peir geta stutt stefnuna, peir vita jafnvel ekki hver hún er.

Prengri skilgreining er að framkvæmd stefnu sé sú vinna sem unnin er sérstaklega í pví augnamiði að koma stefnu skipulagsheildarinnar í framkvæmd. 
Kannski er rétt að bæta við að sá sem vinnuna innir af hendi geti útskýrt hvernig vinnan er liður í að ná peim árangri sem stefnt er að.

Skoðum nú framkvæmd stefnu í samhengi við mótun hennar og par á eftir hvaða leiðir eru helst farnar til að hrinda stefnu í framkvæmd.

\subsection{Mótun og framkvæmd stefnu}

Bækur og greinar um stefnu snúast mun meira um mótun stefnu en framkvæmd hennar. Hér er mótun stefnu (forming strategy) notað sem samheiti við stefnumótun og stefnumörkun. Раð er sú vinna sem unnin er í pví augnamiði að ákvarða (og gera skýrara) hver stefna skipulagsheildarinnar skuli vera. Pegar unnið er að pví að lýsa stefnu skipulagsheildar felst oft í pví einhver stefnumótun pótt pað sé kannski ekki markmiðið með vinnunni.

Mótun og framkvæmd stefnu eru tveir pættir í stefnumiðaðri stjórnun (strategic management) og pví er rétt að skoða pað hugtak svolítið. Peim sem vilja ná betur utan um hugtakið er bent á prennt. Í ýmsum kennslubókum, t.d. hjá Grant (2002), er fjallað um stefnumiðaða stjórnun á aðgengilegan hátt. Moore (1992) gerir í bók sinni grein fyrir framlagi 31 einstaklings til málaflokksins „Strategy and strategic management" og eru pað bæði fræðimenn og ráðgjafar. Í nýlegri grein gerir Runólfur Smári Steinpórsson (2003) ítarlega grein fyrir hugtakinu stefnumiðaðri stjórnun í almennri og fræðilegri umfjöllun.

Greina má stefnumiðaða stjórnun í prjú grunnskref sem eru:

- greiningarvinna (analysis),

- val á kostum (choice) og

- framkvæmd stefnu

Tvö fyrstu skrefin falla undir mótun stefnu. Skrefin prjú eru iðulega samtvinnuð og stefnumiðuð stjórnun parf ekki að takmarkast við pau. Ýmis hugtök ná yfir tvö pessara skrefa og á mynd 1 eru tvö slík hugtök sett í samhengi. 


\begin{tabular}{|c|c|c|}
\hline \multicolumn{3}{|c|}{$\begin{array}{c}\text { Stefnumiðuð stjórnun } \\
\text { Víðtækt hugtak með óljósa og mismunandi merkingu, til dæmis „,markviss } \\
\text { stjórnun sem tekur mið af stefnu skipulagsheildarinnar“. }\end{array}$} \\
\hline \multicolumn{2}{|c|}{$\begin{array}{c}\text { Stefnumótun } \\
\text { skipulagsheildarinnar. }\end{array}$} & $\begin{array}{c}\text { Framkvæmd stefnu } \\
\text { Vinna sem er unnin í } \\
\text { pví augnamiði að } \\
\text { framkvæma stefnu } \\
\text { Vinna sem er unnin í pví augnamiði að móta stefnu } \\
\text { skipulagsheildarinnar. }\end{array}$ \\
\begin{tabular}{c|c} 
Greiningarvinna \\
Greining á umhverfi, \\
auðlindum, \\
hagsmunaaðilum og á kostum \\
öðru sem skiptir máli \\
fyrir ákvarðanir um \\
stefnu.
\end{tabular} & $\begin{array}{c}\text { Kostirnir geta varðað margt, } \\
\text { t.d. gildi, viðskiptastefnu, } \\
\text { markaði og tækninotkun. }\end{array}$ & $\begin{array}{c}\text { Stefnumarkandi áætlanagerð } \\
\text { Hugsunin er að koma stefnu skipulagsheildarinnar í } \\
\text { framkvæmd með pví að gera áætlun (val á kostum) sem } \\
\text { fylgt er eftir (framkvæmd stefnu). }\end{array}$ \\
\hline
\end{tabular}

Mynd 1. Hugtök er tengjast skrefum við mótun og framkvæmd stefnu.

Orðið stefnumótun er mikið notað og í misjafnri merkingu og stundum er orðið stefnumótunarferli notað í sömu eða svipaðri merkingu. Mælt er gegn pví að nota orðið stefnumótun sem pýðingu á strategy (p.e. sem samheiti orðsins stefna) eins og stundum er gert, meðal annars vegna pess að pá er erfitt að pýða forming strategy svo að vel sé.

Stefna mótast á margan hátt. Í flestum tilvikum verja æðstu stjórnendur fyrirtækja miklum tíma í stefnumótun án pess að peir séu að vinna að formlegri stefnumótun. Flest fyrirtæki og stofnanir gera af og til átak í stefnumótunarvinnu sem getur varað allt frá nokkrum klukkustundum upp í nokkrar vikur. Oft er pátttakan takmökuð við æðstu stjórnendur en stundum taka mun fleiri starfsmenn pátt í henni. Stundum eru utanaðkomandi ráðgjafar fengnir til að stýra vinnunni eða vinna hluta hennar. Stundum er petta árviss atburður og stundum á stefnumótun sér stað af sérstöku tilefni, t.d. pegar miklar breytingar eiga sér stað í rekstrarumhverfinu.

Stefnumarkandi áætlanagerð (strategic planning, long term planning) var áður mun ríkari páttur í stefnumiðaðri stjórnun en nú er (sjá t.d. Lynch 2000, bls. 780-786). Eflaust má deila um hvort stefnumarkandi áætlanagerð hefjist með greiningarvinnu eða ekki, en í öllu falli spannar hún val á kostum og framkvæmd stefnu.

Porkell Sigurlaugsson (1994) notar í riti sínu orðin stefnumarkandi áxtlanagerð í grófum dráttum í merkingunni stefnumiðuð stjórnun, sem hann kallar reyndar stefnumarkandi stjórnun. Par er orðið stefnumörkun stundum notað í merkingunni stefna.

Orðin hlutverk (tilvist, mission), gildi (values) og framtíðarsýn (vision) eru oft notuð í vinnu við stefnumótun og í nokkuð misjafnri merkingu. Pessi hugtök koma yfirleitt ekki mikið við sögu í framkvæmd stefnu og pví ekki fjallað um pau hér, að 
öðru leyti en pví að eftirfarandi skýringar á peim eru dregnar fram (sjá m.a. Niven 2003):

- Hlutverk: Hvers vegna er skipulagsheildin til staðar?

- Gildi: Hvaða grunngildi styðst skipulagsheildin við?

- Framtíðarsýn: Hvernig viljum við sjá skipulagsheildina í framtíðinni?

Stefnumótandi ákvörðun (stefnumarkandi ákvörðun, strategic decision) er ákvörðun sem ber eftirfarandi einkenni (Grant 2002, bls. 17):

- Ákvörðunin er mikilvæg.

- Ákvörðunin felur í sér ráðstöfun mikilla bjarga (fjármagns).

- Ákvörðunin hefur varanleg áhrif.

Stefnumótandi ákvarðanir geta hvort sem er verið liður í stefnumótun (t.d. ákvörðun um að hefja markaðssetningu og sölu í Japan) eða liður í framkvæmd stefnunnar (t.d. ákvörðun um að kaupa tiltekið japanskt smásölufyritæki).

Ef stjórnendum finnst stefnan ekki vera nægilega skýr geta peir gert tvennt (gjarnan samofið), annars vegar að endurmóta stefnuna (petta er pað sem almennt kallast stefnumótun) og hins vegar að festa á blað mikilvæga pætti stefnunnar sem aðeins eru til í hugum manna. Hið síðarnefnda er mjög mikilvægt atriði fyrir framkvæmd stefnunnar og er fjallað um pað víðar í pessari grein. Algengast er að nota eingöngu texta við petta verk. Með útbreiðslu stefnumiðaðs árangursmats er orðið algengt að stefnukort séu notuð til að lýsa stefnu en leiðbeiningar um slíka vinnu má finna í Kaplan og Norton (2004) og Ackermann, Eden og Brown (2005).

\subsection{Leiðir til að framkvæma stefnu}

Í pessum undirkafla er gerð almenn en stutt grein fyrir helstu leiðum til að framkvæma stefnu en eftir að búið er að fjalla um stefnumiðað árangursmat í næstu premur köflum verður sérstaklega horft á pátt peirrar aðferðafræði í framkvæmdinni.

Framkvæmd stefnu er einn páttur í stefnumiðaðri stjórnun og samkvæmt mynd 1 er stefnumótun annar grundvallarpáttur hennar. Pessir tveir pættir purfa ekki að vera aðskildir og geta tvinnast saman.

Ljóst má vera að framkvæmd stefnu felst í mörgum atriðum sem tvinnast saman á flókinn hátt. Hér verða dregin fram helstu atriði sem leika oft stórt hlutverk í framkvæmd stefnu.

- Breytingar á skipuriti. Slíkar breytingar eru gerðar sjaldan en gjarnan í framhaldi af stefnumótunarvinnu. Pær geta verið lykill að árangursríkri framkvæmd stefnu en duga samt skammt. Раð má segja að slæmt skipurit geti gert framkvæmd erfiða en gott skipurit opni fyrir möguleika á markvissri framkvæmd.

- Stefnumarkandi áætlanagerð. Um hana var rætt hér að framan. 
- Fjárhagsáætlun (butgeting) er tæki sem flestar skipulagsheildir styðjast við og sumir telja að slík áætlun sé lykiltæki við framkvæmd stefnu. Um petta má deila og mætti ræða í lagnri grein en hér er ekki rúm fyrir slíkt. Tvennt er rétt að benda á í pessu sambandi. Segja má að markmiðið með pví að gera fjárhagsáætlun sé tvípætt, annars vegar að skapa ramma fyrir einstaka pætti starfseminnar (t.d. deildir) og hins vegar að sýna í verki á hvað skuli leggja áherslu. Margir draga stórlega í efa að fjárhagsáætlanir virki eins og til stendur, sjá t.d. Neely, Bourne og Adams (2003).

- Breytingaverkefni sem liður í framkvæmd. Oft leiðir stefnumótunarvinna af sér ákvarðanir um breytingar á stefnu eða starfsháttum sem kalla á sérstök verkefni sem parf að framkvæma. Dæmi um pað er ef fyrirtæki ætlar að hasla sér völl á nýjum markaði. Í sumum bókum og greinum er látið sem framkvæmd stefnu snúist mest um slík verkefni en pað er mjög takmörkuð sýn.

- Stefna hríslast niður í fyrirtæki eða stofnun með pví að yfirmenn stjórna undirmönnum. Allur gangur er á pví hve stefnumiðuð sú stjórnun er.

- Árangursmat (performance measurement) tekur á sig ýmsar myndir. Hjá fyrirtækjum hefur verið lögð mest áhersla á fjárhagslega árangursmælikvarða en síðasta áratuginn hafa stjórnendur, ráðgjafar og fræðimenn lagt áherslu á að nota einnig ýmsa aðra mælikvarða. Í opinbera geiranum má merkja sífellt auknar kröfur um árangursmat.

- Algengt er að fyrirtæki og stofnanir noti gildi (values) til að miðla mikilvægum páttum í stefnunni til allra starfsmanna og koma stefnunni pannig í framkvæmd.

Sumar af peim leiðum sem taldar eru upp hér að framan snúa fyrst og fremst að stjórnendum en aðrar að öllum starfsmönnum. Prjár fyrstu leiðirnar falla klárlega í fyrri flokkinn en sú síðasta í pann síðari.

Ein leið til að greina starfsemi í skipulagsheildum í tvennt er að greina að daglegan rekstur og próunarverkefni. Pegar hugað er að framkvæmd stefnu er nálgunin ólík eftir pví hvort á við. Með próunarverkefnunum er unnið að pví að gera marktækar breytingar á starfseminni í pá átt sem menn vilja fara, p.e. í samræmi við markaða stefnu. Dagleg starfsemi er samkvæmt orðanna hljóðan og breytist og próast yfirleitt smátt og smátt. Framkvæmd stefnu getur snúist um hvort tveggja.

\subsection{Lykilstarfsmenn og skipurit}

Samkvæmt niðurstöðum rannsókna sem kynntar eru í bókinni Good to great (Collins 2001) er fyrsti lykillinn að mikilli velgengni fyrirtækja að æðsti stjórnandi sé mjög hæfur stjórnandi. Í bókinni er útskýrt hvað pað merkir að vera mjög hæfur stjórnandi en eitt af pví sem hann gerir er að fá mjög gott fólk í lið með sér. Рað blasir reyndar við að mjög mikilvægt er að starfsmenn séu hæfir til að vinna störf sín, meðal annars að peir búi yfir æskilegri pekkingu, pjálfun og viðhorfum. Án pessa duga einhver kerfi eða stjórnunaraðferðir skammt. 
Öll starfsemi í skipulagsheildum tekur mið af formlegu skipuriti pótt misjafnt sé hve mikil áhrif pað hefur á starfsemina og hve nákvæmlega er farið eftir pví í daglegum störfum. Önnur skipulagsatriði geta líka haft veruleg áhrif og má nefna starfslýsingar, upplýsinga- og boðmiðlun og skipulag vinnustaðar, m.a. staðsetningu starfsmanna. Раð hvernig ábyrgð er skilgreind (m.a. umboð til athafna) er náskyldur áhrifapáttur. Gott skipulag getur auðveldað framkvæmd stefnu verulega og óheppilegt skipulag torveldað hana og stundum getur breyting á skipulagi hraðað framkvæmd. Pessi mikilvægu atriði verða ekki rædd frekar í pessari grein.

\section{Stefnumiðað árangursmat}

Kaplan og Norton kynntu hugtakið Balanced Scorecard (BSC) árið 1992 en síðan pá hefur pað próast mikið, bæði í höndum peirra og annarra. Líta má á BSC sem aðferðafræði sem býður upp á tvö meginverkfæri. Fæst í BSC-aðferðafræðinni er nýtt en höfundarnir hafa byggt upp heilsteypta aðferðafræði á nýjan hátt. Líklega er mesta nýjungin víddirnar fjórar (perspectives) en aðferðafræðin gengur út á að skilgreina mælikvarða sem lýsa árangri sem snerta fjármál, viðskiptavini, ferla og mannauð (lærdóm og pekkingu).

Stefnumiðað árangursmat er hér notað sem pýðing á BSC. Ekki er reynt að segja frá aðferðafræðinni nákvæmlega eins og Kaplan og Norton gera (t.d. í Kaplan og Norton 2001) heldur einnig tekið tillit til hvernig aðrir hafa notað hana og lýst henni.

Pótt nokkur munur sé á pví hvernig fræðimenn lýsa stefnumiðuðu árangursmati (BSC) pá er hann lítill miðað við hve innleiðing aðferðarinnar getur tekið á sig ólíkar myndir. Innleiðingin á BSC hlýtur að taka mið af aðstæðum og pví er eðlilegt að hver fari sína leið. Við petta bætist svo að algengt er að fyrirtæki og stofnanir segist hafa innleitt BSC en hafa ekki unnið í samræmi við aðferðafræðina. Dæmi um slíkt eru svokölluð skorkort sem eru pannig að mælikvarðarnir endurspegla engan veginn stefnuna (en yfirleitt er ekki hægt að segja opinberlega frá einstökum dæmum um slíkt).

Stefnumiðað árangursmat er í senn einföld og flókin aðferðafræði og margar hindranir í vegi peirra sem vilja styðjast við aðferðafræðina. Рað reynist t.d. fáum létt verk að búa til stefnukort og pað er eðli málsins samkvæmt erfitt að finna góða mælikvarða. Óljós hugtök og orð með breytilega merkingu hafa líka flækst fyrir fólki í vinnu við mótun og framkvæmd stefnu.

Aðferðafræðin býður fyrst og fremst upp á tvö verkfæri sem má útfæra og nota á marga vegu. Annað peirra er skorkort (scorecard eða balanced scorecard) og stundum er pessu verkfæri ruglað saman við aðferðafræðina. Mörg dæmi eru til að mynda um að skorkort séu gerð án pess að aðferðafræðinni sé beitt. Hitt verkfærið er stefnukort (strategy map). Í næstu tveimur köflum er fjallað sérstaklega um pessi tvö meginverkfæri BSC. 


\subsection{Stefnumiðað árangursmat í hnotskurn}

Byrjum á að skoða lýsingu frá Stjórnvísi, félagi um framsækna stjórnun, tekna af vefsíðu félagsins í sept. 2003:

Samhæft árangursmat (BSC) er verkfæri í árangursstjórnun til að hrinda markaðri stefnu í framkvæmd og tengja hana daglegri starfsemi. Samhæft árangursmat er í raun allt í senn samskiptatæki, mælitæki, stjórntæki og aðgerðadrifið tæki. Раð miðlar stefnu til allra starfsmanna og mælir framgang hennar. Pannig fást vísbendingar um pann árangur sem áunnist hefur. Stjórnendur nýta síðan niðurstöður árangursmælinga til að byggja ákvarðanir sínar á og grípa til aðgerða ef pörf krefur.

Stefnumiðað árangursmat er aðferðafræði til að auðvelda framkvæmd stefnu á markvissan hátt með pví að útfæra stefnuna, miðla henni til starfsmanna og fylgjast með hvernig gengur að framkvæma hana. Stefnumiðað árangursmat er pannig stjórntæki og kerfi fyrir upplýsingasöfnun og -miðlun.

Í einföldu máli má segja að aðferðafræðin snúist um eftirfarandi atriði, p.e. að eftirfarandi sé ",andi BSC":

- Stefnan er gerð skýrari og útfærð nánar en algengast er, meðal annars með pví að lýsa henni með stefnukorti eða stefnukortum. Orsakatengslum er lýst og pau koma gjarnan fram á stefnukortunum.

- Skilgreint er safn af markmiðum (stundum eru petta m.a. „key success factors“) og mælikvörðum (stundum eru petta m.a. „key performance indicators“). Petta safn af mælikvörðum ásamt tölum sem peir gefa og fleiri upplýsingum er kallað skorkort og á safnið að vera í jafnvægi og endurspegla stefnuna.

- Stefnu fyrirtækisins er markvisst komið til skila til starfsmanna pess með stefnu- og skorkortum. Petta auðveldar peim að haga störfum sínum og ákvörðunum í samræmi við stefnu fyrirtækisins. Hugtakið hríslun stefnu (cascading strategy) merkir að gerð eru skorkort eða stefnukort fyrir ýmsar einingar fyrirtækisins (t.d. deildir) sem byggjast á skorkorti eða stefnukorti næstu einingar fyrir ofan (t.d. sviðs).

- Reglulegar stjórnendaupplýsingar (oft mánaðarlegar) verða markvissari og segja meira um pað hvernig gengur að framkvæma stefnu fyrirtækisins en algengt er. Hefðbundnar fjárhagsupplýsingar eru hluti af pessum upplýsingum en einnig aðrar upplýsingar sem væru sumar ella ekki fyrir hendi.

\subsection{Próun BSC}

BSC-aðferðafræðin á upphaf sitt að rekja til rannsóknar- og próunarverkefnis frá árinu 1990 par sem mælingar hjá nokkrum fyrirtækjum sem póttu skara fram úr voru skoðaðar og próaðar og ályktanir dregnar, sjá Kaplan og Norton (1992). Aðferðafræðin hefur próast mikið síðan pá og má með töluverðri einföldun skipta próuninni í prjú skref, sjá t.d. umfjöllun í Larsen (2002): 
- Mælingakerfi fyrirtækis er útvíkkað pannig að jafnvægi sé milli meginrekstrarpátta fyrirtækisins. Pessar árangursmælingar eru settar fram í skorkortum. Sjá Kaplan og Norton (1992).

- Hið útvíkkaða mælingakerfi er tengt stefnu fyrirtækisins náið pannig að skorkortin endurspegli stefnuna. Sjá Kaplan og Norton (1996).

- Aðferðafræðin snýst um framkvæmd stefnu og að mæla með skorkortum hvernig gengur að framfylgja henni en áhersla er lögð á að lýsa stefnunni fyrst með stefnukortum og byggja síðan skorkortin á peirri vinnu. Sjá Kaplan og Norton (2000 og 2001).

Nýjasta bók Kaplans og Nortons (2004) fjallar um stefnukort. Í henni er pó engin grundvallarbreyting gerð á BSC heldur felst próun aðferðarinnar fyrst og fremst í pví að höfundarnir setja fram sýn sína á pví hvaða atriði koma oft fyrir í stefnukortum og hvernig geti verið gott að byggja pessi kort upp.

BSC-aðferðafræðin var upphaflega próuð fyrir fyrirtæki. Síðan fóru ýmsar stofnanir og samtök að nota hana og útfæra og er víða unnið að pví að taka aðferðina upp í opinbera geiranum. Á Íslandi má nefna að fjölmargar ríkisstofnanir og sveitarfélög eru að vinna að pví að taka aðferðina upp og nokkrar tóku hana í notkun á árinu 2004, t.d. Umferðarstofa. Reykjavíkurborg leggur mikla áherslu á að taka aðferðina upp og par taka mjög margir pátt í pví. Ríkisendurskoðun (2003) hefur gefið út rit um stefnumiðað árangursmat og vill með pví stuðla að pví að opinberar stofnanir taki pessa aðferð í notkun. Pótt mörg íslensk fyrirtæki séu einnig að vinna að taka pessa aðferð upp pá virðist pað ganga hægar par. Af erlendum skrifum má ráða að próunin sé svipuð í mörgum löndum.

\section{Stefnukort}

Reynsla höfundar af pví að fylgjast með fjölmörgum læra á og vinna með stefnukort (strategy map) segir að tiltölulega fáir fái góðan skilning á stefnukortum á skömmum tíma. Svo virðist sem margir purfi 2-10 klst. kennslu og pjálfun til að geta tekið beinan pátt í próun peirra. Mjög fáir virðast geta beitt stefnukorti sem öflugu verkfæri. Рað má bera saman listina að mála andlitsmyndir og teikna stefnukort. Í báðum tilvikum snýst verkefnið um að greina pað sem er einkennandi og koma pví á blað.

Stefnukort eiga að lýsa stefnu skipulagsheildar (peim árangri sem stefnt er að og hvernig honum skuli náð) með pví að sýna meginatriði stefnunnar og orsakasamband milli peirra. Venjulega eru æðstu markmið höfð efst á kortinu (t.d. hagnaður eða ánægðir viðskiptavinir) og síðan koma undirmarkmið og árangurspættir og jafnvel annars konar atriði. Atriðin eru tengd innbyrðis með örvum sem merkja "stuðlar að“. Útfærsla á stefnukortum getur verið afar mismunandi að mörgu leyti.

Mynd 2 sýnir dæmi um íslenskt stefnukort par sem örvar eru á milli einstakra markmiða. Í sumum stefnukortum eru aðeins örvar á milli vídda og stundum er pessu blandað saman. 


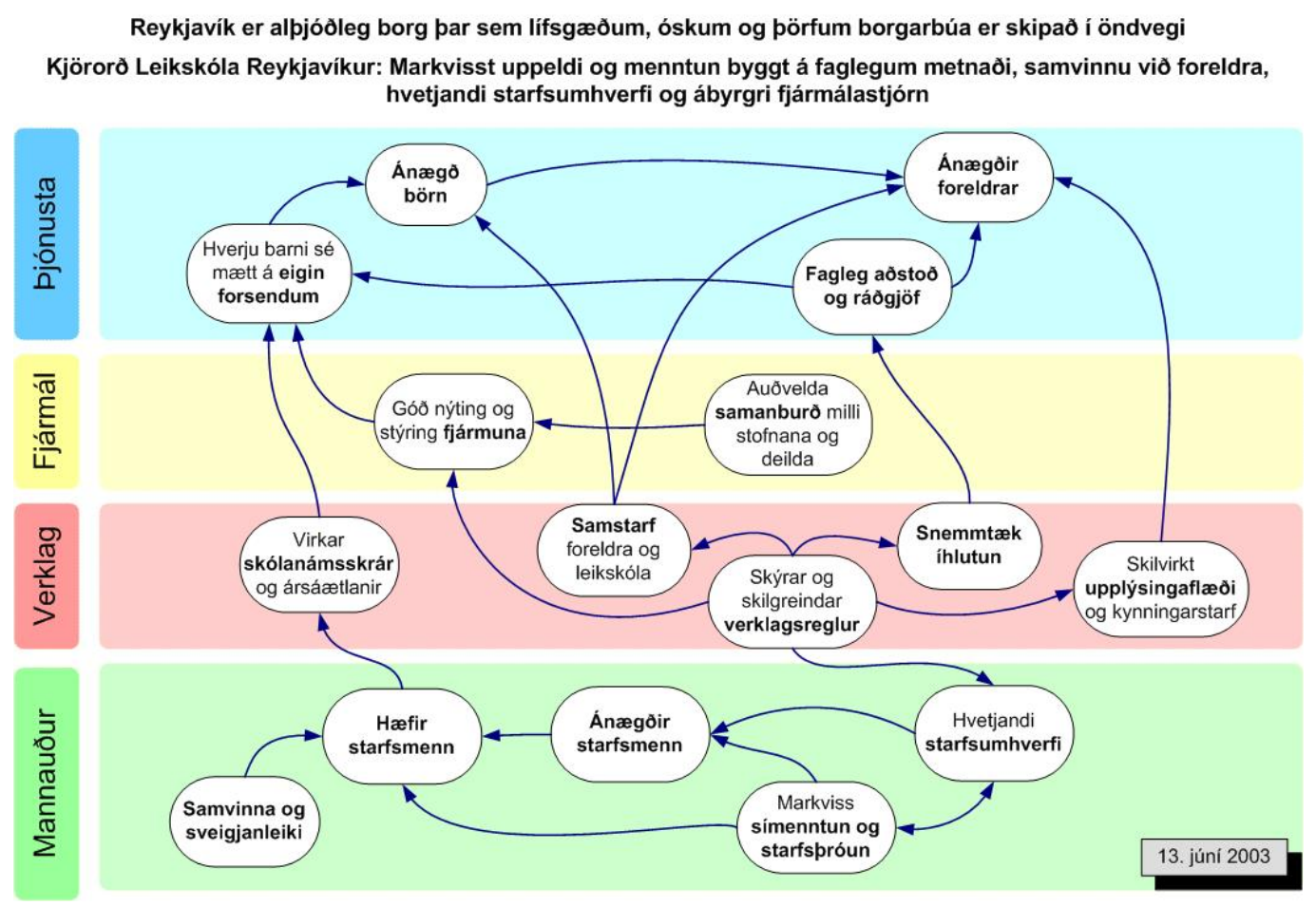

Mynd 2. Stefnukort Leikskóla Reykjavíkur.

Nokkur dæmi um stefnukort komu fram í Kaplan og Norton (1996) án pess að hugtakið "stefnukort" væri notað. Í Kaplan og Norton (2001) leika stefnukort hins vegar stórt hlutverk. Enn er nokkuð um að fræðimenn, starfsmenn og jafnvel ráđgjafar sjái BSC-aðferðafræðina í pví ljósi sem hún var sett fram í Kaplan og Norton (1996) en pekki ekki til stefnukorta. Hér á landi eins og erlendis hafa margir unnið að taka pessa aðferðafræði upp án pess að styðjast við stefnukort, oft vegna pess að pekking á pví verkfæri var ekki til staðar. Á Íslandi breyttist petta mjög hratt á árunum 2002 og 2003 og nú er algengast að stefnukort séu gerð á undan skorkortum.

Kaplan og Norton telja verkfærið stefnukort (strategy map) vera eitt merkasta framlag BSC-aðferðafræðinnar. Kaplan og Norton segja (2001, bls. 10):

Unlike in the financial domain, where standard frameworks such as general ledgers, income statements, and balance sheets exist to document a financial plan, no generally accepted framework exist for describing strategy.

og

From this base of experience, we developed a general framework for describing and implementing strategy that we believe can be as useful as the framework income statement, balance sheet, statement of cash flows - used by financial managers for financial planning and reporting. The new framework, which we call a "strategy map", is a logical and comprehensive architecture for describing strategy. It provides the foundation for designing a Balanced Scorecard that is the cornerstone of a new "strategic management system." 
Stefnukort eru pó mun eldri en BSC-aðferðafræðin og pví er hæpið hjá Kaplan og Norton að segja „... we developed ...“ í tilvísuninni hér að framan. Pessi kort komu væntanlega fyrst fram óformlega í aðgerðarannsóknum árið 1983 (Eden o.fl. 1983) og formlega árið 1989 (Eden 1989) en líta má á stefnukort sem einn flokk tengslarita.

Eitt af pví sem einkennir nær öll stefnukort frá Kaplan og Norton er að víddirnar fjórar (eða afbrigði af peim) koma fram á kortinu. Í nýjustu bók peirra (Kaplan og Norton 2004), Strategy Maps: Converting Intangible Assets into Tangible Outcomes, draga peir fram stefnupemu (strategic theme). Peir telja sig nú hafa greint nokkur stefnupemu sem eru mjög algeng hjá fyrirtækjum og hafa allt að pví staðlað stefnukortin sín.

Stefnu fyrirtækja og stofnana hefur um árabil fyrst og fremst verið lýst með orðum. Sú aðferð getur hentað vel pegar ekki er ætlunin að lýsa stefnunni ítarlega eða tengja daglegar aðgerðir starfsmanna við hana. Ef, hins vegar, ætlunin er að lýsa stefnunni pað ítarlega að sú lýsing hafi veruleg áhrif á störf einstaklinga í skipulagsheildinni er æskilegt eða nauðsynlegt að grípa til annarra aðferða. Óhætt er að segja að stefnukort veiti möguleika á að lýsa stefnu á annan og betri hátt en unnt er með öðrum aðferðum. Jafnvel má segja að stefnukort sé eina verkfærið sem er sérstaklega hentugt til að lýsa stefnu á djúpan og skilvirkan hátt ef stefnan er flókin eða ítarleg.

Grundvallaratriði í BSC-aðferðafræðinni er að peir mælikvarðar sem settir eru fram í skorkorti endurspegli í heild sinni stefnuna. Petta er pó hægara sagt en gert. Höfundur pessarar greinar hefur séð og fengið upplýsingar um mörg skorkort sem endurspegla stefnuna mjög illa en af augljósum ástæðum er sjaldnast hægt að segja frá slíkum dæmum opinberlega. Ef vönduð stefnukort eru gerð á undan skorkortum verður vinna við skorkortin mun auðveldari en ella og meiri líkur á að pau endurspegli stefnuna vel.

Stefnunni er komið á framfæri við starfsmenn bæði með stefnukortum og skorkortum. Stundum getur verið eðlilegt að almennir starfsmenn sjái aðeins skorkort eða aðeins stefnukort en ekki er eðlilegt að stjórnendur styðjist eingöngu við skorkort ef fylgja á stefnumiðuðu árangursmati eða BSC eins og aðferðin er notuð núna.

\section{Skorkort}

Á skorkorti eru sett fram markmið sem koma fram í stefnukortinu eða eru tengd atriðum á stefnukortinu. Fyrir hvert markmið er einn mælikvarði eða fleiri sem segja til um hvernig gengur að ná markmiðinu. Segja má að mælikvarðarnir séu burðarásar skorkortanna en markmiðin undirstaðan. Á skorkortum eru einnig ýmsar aðrar upplýsingar og verður farið yfir pær í kafla 6.1. Í kafla 6.2 verður rætt um hugbúnað fyrir stefnumiðað árangursmat.

Að hluta til er skorkort svipað og pað sem kallast mælaborð stjórnandans en pó er margt ólíkt með pessum hugtökum og óæskilegt er að rugla peim saman. 
Próun góðra mælikvarða er hvort tveggja í senn, afar erfitt verkefni og afar mikilvægt verkefni. Mikilvægið felst ekki aðeins í pví að mælingarnar hafi áhrif á atferli starfsmanna og að pær veiti upplýsingar um starfsemina. Mikilvægi verkefnisins felst einnig í pví að umræður um gangverk fyrirtækisins eru nauðsynlegar til að draga fram mælikvarða og eru pannig liður í mikilvægu lærdómsferli. Tilgangurinn með að gera stefnukort á undan skorkortum er m.a. sá að auðvelda próun góðra mælikvarða.

Hver mælikvarði parf að hafa ýmsa góða eiginleika, meðal annars eftirfarandi (sjá nánar Niven 2003, bls. 204-205):

- Mælikvarðinn tengist stefnunni.

- Auðvelt er að skilja mælikvarðann.

- Hægt er að fá tölur með honum.

- Mælingar eru gerðar oft (nýjar tölur mánaðarlega).

- Ekki ætti að nota mælikvarða sem segja að verkefni sé lokið.

- Mælikvarðinn hafi jákvæð áhrif á starfsmenn.

Ekki nægir pó að hver mælikvarði fyrir sig sé góður heldur parf heildin einnig að vera góð. Skorkortið parf að endurspegla stefnuna fyrir fyrirtækið eða stofnunina í heild eða pann hluta sem pað er gert fyrir. Einnig parf að vera margs konar jafnvægi í pessu safni mælikvarða (balanced scorecard), meðal annars milli leiðandi mælikvarða (lead indicators) og fortíðarmælikvarða (lag indicators). Í stað pess að tala um jafnvægi má allt eins segja að mælikvarðarnir purfi að vera fjölbreyttir og mæla sem flesta pætti sem skipta miklu máli fyrir árangursríka framkvæmd stefnunnar.

\subsection{Upplýsingar á skorkortum}

Fyrir hvern mælikvarða eru ýmsar upplýsingar en pað er mjög breytilegt hvaða upplýsingar eru í skorkortum. Í töflu 2 eru sýndar helstu upplýsingar sem eru algengar á skorkortum. Skoðum hvern dálk fyrir sig.

Víddirnar koma gjarnan fram á skorkortum en ekki alltaf. Par pjóna pær peim tilgangi að auðvelda yfirsýn yfir mælikvarðana sem eru á skorkortinu í heild sinni. 
Tafla 1. Dæmigerðar upplýsingar í skorkorti.

\begin{tabular}{cccccc}
\hline Vídd & Markmið & Mælikvarðar & Niðurstöður & Viðmið & Verkefni \\
\hline Fjármál & Mikil arðsemi & Hagnaður á hlut & 1,56 & 1,05 & \\
Viðskiptavinir & $\begin{array}{c}\text { Aukin markaðs- } \\
\text { hlutdeild }\end{array}$ & Markaðshlutdeild & $23 \%$ & $30 \%$ & $\begin{array}{c}\text { Auglýsinga- } \\
\text { herferð }\end{array}$ \\
Ferli & Lág gallatíðni & Fjöldi galla í \% & $\begin{array}{c}0,7 \%-0,62 \%- \\
0,46 \%-0,63 \%\end{array}$ & $0,50 \%$ & $\begin{array}{c}\text { pjálfun } \\
\text { starfsmanna }\end{array}$ \\
Mannauður & $\begin{array}{c}\text { Ánægja } \\
\text { starfsmanna }\end{array}$ & $\begin{array}{c}\text { Meðaleinkunn úr } \\
\text { viðhorfskönnun }\end{array}$ & 77 & 70 & \\
\hline
\end{tabular}

Markmiðin gegna fyrst og fremst pví hlutverki að tengja mælikvarðana við stefnuna og árangur. Yfirleitt eru nokkur markmið fyrir hverja vídd, gjarnan 2-6 markmið. Algengast er að nota einn eða tvo mælikvarða fyrir hvert markmið en stundum fleiri. Sum markmið geta komið fram á stefnukorti án pess að koma fram á skorkorti en að jafnaði ættu öll markmið á skorkorti einnig að koma fram á stefnukorti. Með pví að setja markmið fram á skorkortum er ljóst til hvers verið er að mæla pað sem mælt er.

Mælikvarðar á skorkortum eru mjög fjölbreyttir. Í ýmsum bókum eru sýndir mælikvarðar sem eru algengir eða hafa reynst vel að mati einhverra (Niven 2002, Becker o.fl. 2001, Huselid o.fl. 2005). Með ýmsum sérsniðnum BSC-hugbúnaði fylgir listi af mælikvörðum. Mergur málsins er samt sá að í hverju tilviki parf að finna út hvaða mælikvarðar henta best og er ekki vænlegt til árangurs að herma eftir öðrum.

Niðurstöðutölur, p.e. tölurnar sem mælikvarðarnir gefa, geta komið úr tölvukerfum fyrirtækisins, fengist með sérstökum mælingum eða verið niðurstaða úr viðhorfskönnunum. Yfirleitt er talið æskilegt að mánaðartölur séu fyrir marga mælikvarða og pá eru gjarnan sýndar tölur fyrir 6-24 mánuði, kannski ekki beint sem tölur heldur sem línurit eða litlar örvar. Niðurstöðutölur

Viðmið (árangursmarkmið, target) er sú niðurstaða sem stefnt er að eða telst vera góð niðurstaða. Viðmið virkar á tvo vegu, annars vegar sem hvatning og hins vegar til að bregðast við ef pau nást ekki. Á skorkortum eru stundum notaðir rauðir, gulir og grænir litir til að sýna hvort tókst að ná viðmiðinu.

Á skorkortum eru gjarnan sýnd verkefni, t.d. umbóta- eða próunarverkefni, sem tengjast tilteknu markmiði eða mælikvarða.

\subsection{Skorkort og hugbúnaður}

Hugbúnaður skiptir litlu sem engu máli við próun skorkorta en getur skipt miklu máli við notkun peirra.

Aðalmálið við próun skorkorta er að skilgreina gott safn af mælikvörðum og algengt er аð pað verk takist ekki. Notkun hugbúnaðar á pessu stigi snýst um að halda utan um upplýsingar (texta og stefnukort en ekki tölur) og best er að nota hugbúnað sem menn eru vanir að nota, t.d. Word og Excel. Fara verður varlega í að taka í notkun nýjan hugbúnað á pessu stigi pví að pað getur tekið tíma og orku frá 
starfsmönnum eins og dæmin sanna og jafnvel skapað andstöðu við að taka upp BSC. Í versta falli veldur petta pví að innleiðingu BSC sé ruglað saman við innleiðingu hugbúnaðar.

Pegar safn mælikvarða liggur nokkurn veginn fyrir er eðlilegt að huga vel að notkun hugbúnaðar. Algengast virðist að Excel sé notað í nokkur ár og síðan sé e.t.v. sérsniðinn hugbúnaður tekinn í notkun. Í sumum tilvikum eru aðstæður pannig að skynsamlegt er að taka strax í notkun sérsniðinn hugbúnað.

Marr og Neely (2003) hafa greint prjár meginástæður fyrir pví að taka í notkun sérhæfðan hugbúnað fyrir BSC:

- Hægt er að flétta saman gögnum úr ýmsum áttum, fyrst og fremst úr ýmsum hugbúnaðarkerfum.

- Sérhæfður hugbúnaður gefur möguleika á að geyma og greina gögnin á ýmsan hátt.

- Sérhæfður hugbúnaður auðveldar upplýsingamiðlun og samskipti.

Раð er margt, en misjafnt, hvað sérsniðinn BSC-hugbúnaður getur gert og í grein Marrs og Neelys er greint frá 31 mismunandi hugbúnaði fyrir BSC. Söfnun, geymsla og miðlun upplýsinga er að sjálfsögðu lykilatriði í pessu máli. Framsetning upplýsinga er eitt af pví sem slíkur hugbúnaður býður gjarnan upp á, t.d. notkun lita og línurita. Einnig er yfirleitt auðvelt að skoða ýmsar upplýsingar sem eru á bak við pað sem sést á skjánum, t.d. undirskorkort eða nánari upplýsingar um einstaka mælikvarða.

\section{Stefnumiðað árangursmat og framkvæmd stefnu}

Í kafla 3 var fjallað almennt um framkvæmd stefnu. Í pessum kafla er athyglinni beint að nokkrum páttum er varða framkvæmd stefnu par sem stefnumiðað árangursmat er líklegt til að geta orðið að gagni. Rétt er að hafa í huga að margt parf аð koma til pannig аð framkvæmd stefnu sé markviss og gangi vel en fátt er nauðsynlegt öllum fyrirtækjum.

Umfjöllun sem pessi hlýtur að bera sterkan keim af pekkingu, reynslu og viðhorfum pess sem skrifar hana. Val á efni í kafla sem pennan fer líka eftir pví hvaða skipulagsheildir eru hafðar í huga, sem og lesendahópurinn. Ef megináherslan væri á stór bandarísk fyrirtæki, svo að dæmi sé tekið, pá væri eðlilegt að haga efni kaflans á nokkuð annan veg en hér er gert.

Í kafla 7.1 er fjallað um pað grundvallaratriði í stjórnun að starfsmenn purfi að vita, vilja og geta. Í 7.2 er rætt um hríslun stefnunnar, p.e. pað verkefni að koma æðstu stefnu skipulagsheildarinnar til starfsmanna með pví að útfæra hana betur og betur. Í köflum 7.3 og 7.4 er starfsemin greind í tvo pætti, annars vegar daglegan rekstur og hins vegar próunarverkefni. Að lokum eru nokkur önnur atriði skoðuð í kafla 7.5.

\subsection{Að vita, vilja og geta}


Til að starfsmenn geti unnið gott starf, t.d. tekið pátt í að framkvæma stefnu fyrirtækisins, purfa peir að

- vita til hvers er ætlast af peim,

- vilja gera pað og

- geta gert pað.

Pessi framsetning byggist óbeint á stjórnendaskóla HP (Hewlett Packard) og Stroebe og Stroebe (1994). Jafnvel má segja að pað að stjórna undirmönnum snúist fyrst og fremst um petta. Skoðum hvert atriði fyrir sig.

\section{Að vita}

Upplýsingar til starfsmanna um til hvers er ætlast af peim eru af ýmsum toga og reyndar er misjafnt hvað peir fá mikið að vita um pað. Sennilega er munurinn mestur eftir pví hvort fyrirmælin snúast um hvernig peir eigi að vinna eða hvaða árangri peir eigi að ná. Aðrar öfgarnar eru að pað sé nákvæmlega skilgreint hvernig eigi að vinna verkið, t.d. starfsmenn sem vinna að viðhaldi flugvéla eða við prif á skurðstofu. Hinar öfgarnar eru pegar æskilegur árangur er skilgreindur en starfsmaður hefur frjálsar hendur um hvernig hann vinnur verkið, t.d. háskólakennari eða lagasmiður. Í pessari grein er einkum fjallað um störf sem eru nær síðara tilvikinu, p.e. starfsmenn sem hafa mikið umboð til athafna.

Pegar starfsmenn hafa mikið umboð til athafna er mikilvægt að ljóst sé eftir hvaða árangri er sóst. Ef vilji er til að framkvæma stefnu markvisst parf að tengja pennan árangur við stefnuna. Ein leið til pess er að nota stefnu- og skorkort pannig að hér getur stefnumiðað árangursmat leikið stórt hlutverk. Nákvæmast er pegar árangurinn er mældur með tölulegum mælikvörðum en yfirleitt er aðeins unnt að ná yfir hluta pess sem skiptir máli með slíkum mælikvörðum og pví ber að fara varlega í pær sakir.

Í sumum tilvikum segja fá orð mikið um æskilegan árangur, t.d. geta gildin haft veruleg áhrif. Yfirleitt er pó pörf fyrir meiri upplýsingar um til hvers er ætlast. Starfslýsingar veita gjarnan einhverjar slíkar upplýsingar.

\section{Að vilja}

Líklega má gera ráð fyrir að flestir starfsmenn vilji vinna gott verk. •að er pó ekki algilt pví að sumir hugsa meira um eigin hagsmuni en hagsmuni fyrirtækisins og vilja fyrst og fremst sleppa auðveldlega frá vinnunni og einstaka starfsmenn vilja skemma fyrir. Раð er pó misjafnt hvað starfsmenn leggja sig hart fram og hægt er að hafa áhrif á pað með ýmsum hætti.

Almennt er talið árangursríkast að fá menn til að leggja sig fram með hvatningu og umbun (til að hvetja menn til dáða). Hótanir og refsingar eru sjaldan æskileg leið og skila oft litlum árangri. Eftirlit getur verið nauðsynlegt og gagnlegt en starfsmenn eiga helst að tengja pað við upplýsingaöflun og umbætur en ekki við refsingu.

Ef BSC er tekið upp í fyrirtæki er sá árangur sem mældur er í skorkortum oft ein af forsendum umbunar. Umbun getur verið fjárhagsleg (laun, bónus, leikhúsmiði) og af öðrum toga (hrós yfirmanns, meira spennandi verkefni en áður). Umbun er 
margslungið fyrirbæri sem verður ekki rætt hér en lesendum er bent á að lesa sér til um pað hjá Daniels (1999). Huga parf bæði að pví fyrir hvað á að umbuna (hvað er góð frammistaða) og hvernig.

Mælikvarðar geta verið mjög hvetjandi og virkað bæði sem vöndur ef illa gengur og sem umbun ef vel gengur. Margir vilja leggja mikið á sig til að ná settu markmiði og gleðjast með öðrum pegar markmiði er náð, sérstaklega ef pað er opinbert og peir hafa átt pátt í að ákveða pað. Ef pessi markmið endurspegla stefnuna pá eru menn að keppast við að framkvæma hana.

\section{Að geta}

Margt parf til að starfsmenn geti sinnt starfi sínu. Рað má flokka í tvennt, hæfni starfsmannsins og starfsskilyrði. Eitt af hlutverkum yfirmanna er að stuðla að pví að undirmenn geti unnið starf sitt svo að vel sé. Til pess að ná pví purfa peir að vita hvernig ástandið er og að stuðla að breytingum eftir pörfum.

Sumir mælikvarðarnir eru til pess fallnir að sýna hve góður árangur starfsmanna hefur verið, p.e. hvort peir hafi getað gert pað sem peir áttu að gera. Aðrir mælikvarðar snúa frekar að pví að mæla forsendur pess að starfsmenn geti gert pað sem peir eiga að gera.

Verkefni á skorkortum eru sum unnin til að auka líkurnar á að starfsmenn geti gert pað sem til er ætlast. Sem dæmi má nefna pjálfunarátak, bætt tölvukerfi og fjölgun starfsmanna.

\subsection{Hríslun stefnu}

Mörg fyrirtæki hafa nokkuð skýra æðstu stefnu (viðskiptastefnu) en almennt orðaða og lítt útfærða. Slík stefna getur stundum haft töluverð áhrif á einstaka starfsmenn. Hins vegar getur stefnan haft mun meiri áhrif (verið meira leiðbeinandi) ef hún er útfærð nánar.

Með hríslun stefnu er átt við að æðsta stefnan sé útfærð pannig að í henni felist nokkuð nákvæm lýsing á hvernig fyrirtækið ætlar að ná peim árangri sem að er stefnt. Petta er gjarnan gert með pví að vinna pað sem má kalla undirstefnur fyrir hluta af starfseminni. Petta geta verið nokkrar eða margar undirstefnur. Pær geta verið í samræmi við skipurit (t.d. stefna fyrir tiltekna deild) eða pvert á skipurit (t.d. gæðastefna).

Pegar unnið er að gerð undirstefnu er byggt á æðri stefnu, sem t.d. kemur fram í stefnukorti og skorkorti. Segja má að með pví að vinna undirstefnuna sé verið að framkvæma æðstu stefnuna en í próun undirstefnu felist jafnframt einhvers konar stefnumótun. Рað er líklega frekar sjaldgæft að til séu skriflegar lýsingar fyrir deildir á pví hvaða árangri er stefnt að og hvernig pað skuli gert, p.e. að til sé stefna fyrir einstakar deildir. Algengara er að verkefnum (og hlutverki) deilda sé lýst og áætlanir um hvernig leysa beri verkefnin liggi fyrir.

Í flestum bókum um BSC er rætt um hvernig stefna er látin hríslast um fyrirtæki með skorkortum. Pá eru gjarnan sumir mælikvarðar í yfirskorkorti einnig látnir 
koma fram í undirkortum (peir erfast) og mælikvarðar í yfirkorti geta verið safnmælikvarðar (yfirleitt summa eða meðaltal) samsvarandi mælikvarða í öllum beinum undirkortum. Aðrir mælikvarðar í undirkortum eru síðan nýir (eiga ekki samsvörun í æðra korti) og tengjast starfseminni í viðkomandi starfseiningu.

Ekki er síður eðlilegt að nota stefnukortin við hríslun. Ýmsir aðgerðarannsóknarmenn (m.a. höfundur greinarinnar) hafa beitt slíkri nálgun í áratugi en á pennan möguleika hefur almennt ekki verið bent í ritum um BSC. Athygli vekur að í upplýsingabæklingi fyrir starfsmenn Reykjavíkurborgar (Reykjavíkurborg 2003) er einvörðungu pessari leið við hríslun lýst. Í vinnu við BSC hjá Reykjavíkurborg árin 2001 og 2002 var hins vegar stuðst við skorkort við hríslunina og nánast ekkert unnið að stefnukortum.

Hríslun parf ekki að fylgja skipuriti. Tökum dæmi: Upplýsingatækni er mikilvæg fyrir flest fyrirtæki og mörg hafa upplýsingatæknideild. Рað getur verið eðlilegt í sumum tilvikum að gera stefnukort og skorkort annars vegar fyrir upplýsingatæknistefnu fyrirtækisins og hins vegar fyrir stefnu upplýsingatæknideildarinnar (sjá Olve o.fl., bls. 22). Sú fyrri gæti pá verið lýsing á pví hvernig upplýsingatæknin auðveldar fyrirtækinu að ná árangri og sú síðari snýst meira um hvernig upplýsingatæknideildin starfar.

\subsection{Dagleg starfsemi}

Mestur tími flestra starfsmanna fer í dagleg störf par sem ekki er sérstök pörf á pví að hugað sé oft eða mikið að stefnunni. Engu að síður getur pað breytt miklu hvort starfsmenn taki tillit til stefnu fyrirtækisins og pví er æskilegt að peir viti hver hún er.

Sjaldgæft er að æðsta stefna fyrirtækis hafi mikil áhrif á starf einstakra starfsmanna. Til að stefna geti haft mikil áhrif á starfsmenn parf hún að standa peim nærri og pess vegna er hríslun mjög mikilvæg. Möguleg áhrif pess að stefnan sé skýr í huga starfsmanna geta t.d. verið:

- hvernig starfsmenn forgangsraða verkum og hvað peir verja löngum tíma í hvert verkefni,

- að peir leggi sig sérstaklega fram um tiltekin atriði, t.d. að ljúka verkefnum fyrir gefin tímamörk,

- að verkferlum og vinnubrögðum sé breytt, t.d. með pví að sleppa óparfa verkpáttum, og

- að starfsmenn taki eftir ýmsu og miðli upplýsingum um pað, t.d. hvaða smáatriði gleðja viðskiptavini.

Stefnumiðað árangursmat getur, ef vel tekst til, stutt við daglegan rekstur og stuðlað að pví að hann sé í takt við stefnu skipulagsheildarinnar. Pað er raunar meginhugsunin við aðferðafræðina.

Meðal ástæðna fyrir pví að stefnan hefur lítil bein áhrif á daglega starfsemi er að starfsmenn pekkja ekki stefnu fyrirtækisins eða sjá ekki hvernig stefnan eigi að hafa áhrif á starf peirra. Með stefnukortum er hægt að miðla stefnunni pannig að 
starfsmenn geti á auðveldan hátt séð hver hún er, auk pess sem hún er pá útfærð nánar en algengast er. Petta er gert með ólíkum hætti og misjafnt er hvaða leið hentar. Sumir hafa t.d. farið pá leið að hafa stefnukort á áberandi stað, t.d. á kaffistofum.

Mælikvarðar (á skorkortum) geta haft mikil áhrif á hegðun. Peir geta haft áhrif á hvernig starfsmaður forgangsraðar verkefnum og valdið pví að hann leggur sig fram um tiltekin atriði. Vel valdir mælikvarðar geta pannig haft afgerandi áhrif á daglegan rekstur. Hér er vert að koma með viðvörun. Mælikvarðar geta haft óæskileg áhrif ef peir eru valdir óskynsamlega og mörg dæmi eru um að slíkt hafi gerst.

\subsection{Dróunarverkefni}

Próunarverkefni eru afar mikilvægur liður í pví að framkvæma stefnu skipulagsheildar. Skiptir pá miklu máli hvaða próunarverkefni eru valin, hvernig pau eru útfærð og hvernig pau eru framkvæmd. Pegar verkefnið snýst um að breyta hegðun eða vinnuumhverfi starfsmanna má líta á breytingastjórnun sem eina vídd verkefnisstjórnunar. Í slíkum tilvikum getur fagleg breytingastjórnun skipt sköpum, sjá t.d. Kotter (1996). Verkefnastjórnun snýst um val og útfærslu á verkefnum og pað að halda utan um upplýsingar um pau verkefni sem eru í gangi en verkefnisstjórnun snýst um stjórnun eins verkefnis.

Í heimi hraðra breytinga og mikillar samkeppni eru flest fyrirtæki með mörg verkefni í gangi sem má kalla próunarverkefni. Pessi verkefni má fella í ýmsa flokka verkefna svo sem vörupróunarverkefni og breytingaverkefni sem eru liður í að framkvæma stefnu fyrirtækisins. Algengt er að fyrirtækjum gangi brösuglega að velja pessi verkefni og halda utan um pau, sjá t.d. Buttrick (2002). Skoðum nánar verkefnaval og hvernig er haldið utan um verkefni.

Verkefnaval snýst um að ákveða hvaða verkefni eru sett af stað og hvaða verkefni eru stöðvuð. Stundum birtist petta sem forgangsröðun verkefna og jafnvel með pví að ákveðið er hve mikið fjármagn fer í hvert verkefni.

Styðjast má við stefnumiðað árangursmat á a.m.k. tvo vegu við verkefnaval. Í fyrsta lagi má gera lista yfir pau verkefni sem eru í gangi eða rætt er um að setja af stað og bera pann lista saman við stefnukortið (sjá m.a. Irwin 2003, bls. 645-646). Pau verkefni sem koma vel heim og saman við pað sem kemur fram á stefnukortinu ættu að hafa ganga fyrir peim verkefnum sem gera pað ekki. Í öðru lagi eru verkefni (í sérstökum dálki) á skorkortum sem tengjast tilteknum mælikvörðum eða markmiðum.

Mikilvægt er að halda utan um upplýsingar um pau verkefni sem eru í gangi (a.m.k. að skilgreina slík verkefni formlega og skrá lykilupplýsingar um pau) en mjög misjafnt er hve vel pað er gert og algengt er að petta reynist fyrirtækjum erfitt. BSC auðveldar ekki pennan pátt neitt að ráði nema helst með pví að listi af verkefnum getur verið í skorkortum.

\section{5 Önnur atriði}


Hér að framan hefur verið fjallað um nokkur lykilatriði við framkvæmd stefnu og hvernig BSC getur komið par að gagni. Hér verður minnst á nokkur atriði í viðbót.

\subsection{1 Áætlanir}

Áætlanir eru nauðsynlegur páttur í starfi fyrirtækja, t.d. starfsáætlanir eða framkvæmdaáætlanir. Cravens (1997) fjallar um gerð og framkvæmd markaðsáætlunar (marketing plan), sem er enn eitt dæmi um áætlun. Skoðum betur pær áætlanir sem algengt er að fyrirtæki og stofnanir geri á síðasta ársfjórðungi fyrir komandi ár. Pessa vinnu má kalla stefnumarkandi áætlanagerð og áætlunin sjálf er stundum kölluð fjárhagsáætlun. Á ensku er notuð fjölmörg orð um petta verkefni, t.d. budgeting, budgeting process, strategic planning og annual planning. Misjafnt er hve mikil vinna er lögð í gerð fjárhagsáætlunar, hve nákvæm hún er og hve bindandi hún er. Vinnubrögð eru einnig ólík.

Hver er pá tilgangur pess að gera fjárhagsáætlun? Segja má að pað pjóni tvennum tilgangi, að úthluta björgum (fjármagni) og að miðla stefnu (áhersluatriðum). Miðað við pessa lýsingu má vera augljóst að BSC getur leyst fjárhagsáætlun af hólmi varðandi hið síðarnefnda.

Greiningu á æskilegum tilgangi fjárhagsáætlunar er að finna í Beinhocker og Kaplan (2002, bls. 51), en par segir:

"Our research persuades us that the exercise can add value if it has two overarching goals. The first is to build 'prepared minds' - that is, to make sure that decision makers have a solid understanding of the business, its strategy, and the assumptions behind that strategy, thereby making it possible for executives to respond swiftly to challenges and opportunities as they occur in real time. ... The second goal is to increase the innovativeness of a company's strategies."

Hér blasir við hvernig BSC getur leyst fjárhagsáætlanir af hólmi að ýmsu leyti. Niven (2002) fjallar um hvernig mögulegt sé að tengja fjárhagsáætlanir við BSC og gefur jafnframt dæmi um fyrirtæki sem hafa alveg hætt við (hefðbundnar) fjárhagsáætlanir.

Erfiðleikar og ókostir við notkun fjárhagsáætlana eru margir, algengir og vel pekktir. Neely o.fl. (2003) telja upp 12 helstu veikleika fjárhagsáætlana, fjalla um helstu leiðir sem farnar eru við gerð peirra og gefa dæmi um stórfyrirtæki sem hafa hætt gerð slíkra áætlana. Beinhocker og Kaplan (2002, bls. 49) segja:

,... the annual strategy review frequently amounts to little more than a stage on which business unit leaders present warmed-over updates of last year's presentations, take few risks in broaching new ideas, and strive above all to avoid embarrassment"

og byggja pessa fullyrðingu á víðtækum rannsóknum.

Berum saman BSC og stefnumarkandi áætlanagerð. Sameiginlegt báðum aðferðunum er pað viðhorf að útfæra purfi stefnuna nánar til að hún geti haft mikil áhrif á dagleg störf. Reginmunur er pó á nálgun pessara tveggja aðferða. Áætlun njörvar margt niður en BSC setur fjölmörg leiðbeinandi markmið. Umboð til athafna er eitt af einkennum BSC (ef útfært er vel) en síður áætlanagerðar. 


\subsubsection{Stjórnendaupplýsingar}

Stjórnendur purfa að fá góðar upplýsingar til að geta áttað sig á hvernig gengur að framkvæma stefnuna og til að geta brugðist við. Peir purfa að fá tölulegar upplýsingar, m.a. úr tölvukerfum skipulagsheildarinnar, og munnlegar upplýsingar. Peir purfa upplýsingar um fjárhagsstærðir, magntölur og ótal margt fleira. Innleiðing á stefnumiðuðu árangursmati getur bætt stjórnendaupplýsingar, jafnvel verulega ef vel tekst til pví að venjulega endurspegla stjórnendaupplýsingar stefnu skipulagsheildarinnar að mjög takmörkuðu leyti.

Góð skorkort veita miklar upplýsingar um hvernig gengur að framfylgja stefnunni en veita að sjálfsögðu langt frá pví allar slíkar upplýsingar. Margir hafa tjáð sig um að BSC breyti umræðum á fundum par sem unnið er að innleiðingu BSC, en fjölmargir starfsmenn geta tekið pátt í slíkum fundum. Petta á einnig við um reglubundna stjórnendafundi, t.d. fundi framkvæmdastjórnar, pannig að umræðan á slíkum fundum snýst í auknum mæli um stefnu og framtíðina eftir að stefnumiðað árangursmat er tekið í notkun.

Framsetning stjórnendaupplýsinga getur skipt miklu, eins og framsetning upplýsinga almennt séð. Stjórnendur purfa að skoða mikið af upplýsingum sem verða sumar til innan fyrirtækisins og aðrar utan pess. Skorkort og hugbúnaður fyrir BSC gefa möguleika á framsetningu peirra upplýsinga sem snúast sérstaklega um framkvæmd stefnunnar.

\subsubsection{Fyrirtækjamenning}

Orðið fyrirtækjamenning er notað yfir mikilvægt hugtak en skilgreiningar á pví eru bæði innbyrðis ólíkar og oft mjög óljósar. Hér er farin sú leið að halda pví opnu hvað petta orð merkir og einnig hvort hér sé í raun um eitt hugtak að ræða eða nokkur mismunandi hugtök. Tengsl BSC við fyrirtækjamenningu eru mikilvæg og pví verða pessi tengsl skoðuð hér, en lítum fyrst á nokkur dæmi um möguleg einkenni á fyrirtækjamenningu:

- hefð er fyrir að mæla mikið og skoða tölur í fyrirtækinu

- samskipti starfsmanna eru lítil eða mikil

- samvinna er mikil

- frumkvæði starfsmanna er lítið eða mikið

- illt umtal um aðra starfsmenn viðgengst í fyrirtækinu

- starfsmenn fyrirtækisins eru kátir

- starfsmenn bera óttablandna virðingu fyrir yfirmönnum

- ótti við breytingar ríkir meðal starfsmanna

Раð аð taka BSC upp getur breytt menningu fyrirtækis á margan hátt. Ef lítil hefð er fyrir pví að mæla ýmis atriði í starfsemi fyrirtækisins mun pað breytast með innleiðingunni. Ef lítið er um tiltekna hegðun (t.d. kátínu starfsmanna) en nokkrir mælikvarðar sem ýta undir slíka hegðun eru skilgreindir má gera ráð fyrir að hún aukist. Stundum er eitt af markmiðunum með innleiðingu einmitt að breyta menningu fyrirtækisins. 
Taka parf mið af fyrirtækjamenningu við innleiðingu BSC. (Reyndar parf að taka tillit til svo margra pátta við hana að hún tekur á sig ótal myndir.) Sem dæmi má nefna petta: Ef ótti eða andstaða við breytingar er eitt af einkennum menningar fyrirtækisins parf að gæta sérstaklega að atriðum eins og góðri upplýsingagjöf, pátttöku starfsmanna og að gefa innleiðingunni nægan tíma. Ef tímaskortur háir mörgum starfsmönnum gæti verið gott að hefja innleiðinguna á mörgum stöðum samtímis og fá utanaðkomandi aðila til að stýra verkefninu.

Menning fyrirtækisins sem í hlut á getur haft mikið um pað að segja hvort skynsamlegt sé að innleiða BSC par. Í sumum tilvikum má gera ráð fyrir að menning fyrirtækisins komi í veg fyrir að vel heppnist að taka BSC upp. Í öðrum tilvikum gæti menning og starfsemi fyrirtækisins verið pannig að innleiðing BSC myndi litlu breyta og hún pví óparft verkefni.

\section{Lokaorð}

Í greininni er gerð tilraun til að greina hver páttur stefnumiðaðs árangursmats (BSC) getur verið í framkvæmd stefnu. Fyrst er fjallað um hugtökin stefna og framkvæmd stefnu. Gerð er grein fyrir meginatriðum aðferðafræðinnar um stefnumiðað árangursmat, sem og próun hennar. Fjallað er almennt um helstu pætti við framkvæmd stefnu og sérstaklega er skoðað hvaða hlutverk stefnumiðað árangursmat getur leikið.

Aðstæður í fyrirtækjum, stofnunum og öðrum skipulagsheildum eru mjög ólíkar og breytast með tímanum. Pví er fátt hægt að segja sem á við um stóran hóp skipulagsheilda, t.d. öll skráð fyrirtæki í Kauphöll Íslands, hvað pá allar skipulagsheildir. Hins vegar er margt sem á við um margar skipulagsheildir, jafnvel mjög ólíkar, og í greininni er reynt að draga fram slík atriði.

Stefnumiðað árangursmat styðst við tvö verkfæri, stefnukort og skorkort. Pau pjóna ólíkum tilgangi en geta bæði auðveldað аð framkvæma suma pætti stefnu skipulagsheildarinnar sem í hlut á. Pau geta til dæmis bæði stuðlað að pví að stefnan sé skýrari og betur útfærð en ella og að pekking starfsmanna á stefnunni sé mikil, en petta eru lykilatriði í aðferðafræðinni.

Stefnukort er tæki til að lýsa stefnu á dýpri hátt en hægt er með góðu móti að gera með orðum einum saman. Stefnukort eru samt vandmeðfarin, bæði vegna pess að fáir hafa pá leikni sem parf til að próa pau og vegna pess að pau eru ekki góð nema pau lýsi lykilatriðum varðandi framkvæmd stefnu en erfitt getur verið að greina slík lykilatriði. Af pessu leiðir líka að við gerð stefnukorta fer gjarnan fram einhver stefnumótun.

Megintilgangurinn með skorkortum er að hafa áhrif á hegðun starfsmanna og gefa stjórnendum upplýsingar. Ef safn mælikvarða í skorkorti endurspeglar stefnuna stuðlar pað að pví að hegðun starfsmanna sé í samræmi við stefnuna og stjórnendur fái upplýsingar um hvernig gengur að framkvæma hana. Reynslan sýnir að mörg stefnukort endurspegla stefnuna illa, jafnvel alls ekki. Með pví að lýsa stefnunni með stefnukorti par sem einstök atriði stefnunnar eru sett fram sem markmið og pessi 
markmið síðan sett inn í skorkortið reynist oft mun auðveldara en ella að próa safn mælikvarða sem endurspeglar stefnuna.

Í greininni er reynt að draga fram hvernig stefnumiðað árangursmat getur nýst við framkvæmd stefnu en ekki er fjallað um hvaða skipulagsheildir ættu að innleiða stefnumiðað árangursmat og hvernig.

\section{Heimildir}

Ackermann, F., Eden, C. \& Brown, I. (2005). The Practice of Making Strategy: A Step-byStep Guide. London: SAGE Publications.

Becker, B. E., Huselid, M. A. \& Ulrich, D. (2001). The HR scorecard : Linking People, Strategy, and Performance. Boston: Harvard Business School Press.

Beer, M. \& Eisenstal, R. A. (2000). The Silent Killers of Strategy Implementation and Learning. MIT Sloan Management Review, 41 (4), 29-40.

Beinhocker, E. D. \& Kaplan, S. (2002). Tired of Strategic Planning? The McKinsey Quatrely, 2002 special edition: Risk and resilience, 49-57.

Buttrick, R. (2000). Project Workout. FT/Prentice Hall.

Collins, J. (2001). Good to Great. New York: Harper Business.

Cravens, D. W. (1997). Strategic Marketing. London: IRWIN.

Daniels, A. C. (1999). Bringing Out the Best in People. New York: McGraw-Hill.

Eden, C., Jones, S. \& Sims, D. (1983). Messing about in problems. Oxford: Pergamon Press.

Eden, C. (1989). Using cognitive mapping for strategic options development and analysis (SODA). Í Rosenhead, J. (ritstj.). Rational Analysis for a Problematic World (bls. 21-42). Chichester: John Wiley \& Sons.

Grant, R. M. (2002). Contemporary Strategy Analysis. Cornwall: Blackwell Publishers.

Hendry, J., Johnson, G. \& Newton, J. (1994). Strategic Thinking: Leadership and the Management of Change. Chichester: John Wiley \& Sons.

Huselid, M. A., Becker, B. E. \& Beatty, R. W. (2005). The Workforce Scorecard: Managing Human Capital To Execute Strategy. Boston: Harvard Business School Press.

Irwin, D. (2002). Strategy mapping in the public sector. Long Range Planning, 35, 637647.

Kaplan, R. S. \& Norton, D. P. (1992). The Balanced Scorecard - Measures That Drive Performance. Harvard Business Review, 70 (1), 71-79.

Kaplan, R. S. \& Norton, D. P. (1996). The Balanced Scorecard: Translating strategy into action. Boston: Harvard Business School Press.

Kaplan, R. S. \& Norton, D. P. (2000). Having trouble with your strategy - then map it. Harvard Business Review, 74 (5), 167-186. 
Kaplan, R. S. \& Norton, D. P. (2001). The Strategy Focused Organization: How balanced scorecard companies thrive in the new business environment. Boston: Harvard Business School Press.

Kaplan, R. S. \& Norton, D. P. (2004). Strategy Maps: Converting Intangible Assets into Tangible Outcomes. Boston: Harvard Business School Press.

Kotter, J. P. (1996). Leading Change. Boston: Harvard Business School Press.

Lynch, R. (2000). Corporate Strategy. Harlow: Pearsons Education Limited.

Larsen, H. T. (2002). Hvor blev balancen af - om udviklingen i Balanced Scorecard begrebet. Ledelse og Erhversokonomi, 2, 83-93.

Marr, B. \& Neely, A. (2003). Automating the Balanced Scorecard - Selection criteria to identify appropriate software applications. Measuring Business Excellence, 7 (3), 29-36.

Moore, J. I. (1992). Writers on Strategy and Strategic management. England: Penguin Business.

Neely, A., Bourne, M. \& Adams, C. (2003). Better budgeting or beyond budgeting? Measuring Business Excellence, 7 (3), 22-28.

Niven, P. R. (2002). Balanced Scorecard step by step: Maximizing performance and maintaining results. New York: John Wiley \& Sons.

Niven, P. R. (2003). Balanced Scorecard step by step for Government and Nonprofit Agencies. New York: John Wiley \& Sons.

Olve, N. G., Petri, C. J., Roy, J. \& Roy, S. (2003). Making Scorecards Actionable balancing stratetgy and control. Chichester: John Wiley \& Sons.

Reykjavíkurborg (2003). Samhæft árangursmat (Hvað, hvers vegna og hvernig). Reykjavíkurborg.

Ríkisendurskoðun (2003). Kennitölur um umsvif og árangur - Stefnumiðað árangursmat í ríkisrekstri. Ríkisendurskoðun.

Runólfur Smári Steinpórsson (2003). Stefnumiðuð stjórnun: Fimm greiningarlíkön. Tímarit um viðskipti og efnahagsmál, 2003, 27-54. Viðskipta- og hagfræðideild Háskóla Íslands.

Stroebe, G. H. \& Stroebe, R. W. (1994). Arbeitshefte Führungspsychologie. Heidelberg: I. H. Sauer-Verlag GmbH.

Porkell Sigurlaugsson (1994). Stefnumarkandi áxtlanagerð. Reykjavík: Viðskiptafræðistofnun Háskóla Íslands og Framtíðarsýn. 